\title{
Transformation of the concept of legal system in the conditions of globalisation
}

\author{
Svetlana Arkadievna Sofronova $^{11}$, Elena Nikolaevna Kozhina $^{1}$, Andrey Nikolaevich \\ Kryukov $^{1}$, Olga Yurievna Kryukova ${ }^{2}$ and Dimitri Oleynik ${ }^{3}$ \\ ${ }^{1}$ Vologda Institute of Law and Economics Federal Penitentiary Service of Russia, Faculty of Law, \\ Vologda, Russia \\ ${ }^{2}$ Vologda Institute of Law and Economics Federal Penitentiary Service of Russia, Executive research \\ department, Vologda, Russia \\ ${ }^{3}$ University of Wismar - University of Applied Sciences: Technology, Business and Design, \\ Department of Economic Sciences, Wismar, Germany
}

\begin{abstract}
The purpose of the study is to identify the main trends and factors influencing the development of the theoretical concept of the legal system and possible categories derived from it. The methodological basis of the research is represented by such scientific methods as dialectical, logical, historical, predictive, systemic analysis and content analysis. This made it possible, in view of achievement of the said objective, to analyse the works of Russian and foreign comparativists, both the founders of modern comparative jurisprudence and novice researchers, as well as the materials of scientific conferences on the problem under investigation. The result of the study was the conclusion that the complex nature of the category "legal system" makes it possible to form a holistic picture of legal reality. At the same time, the result of the research depends on the criterion laid as a basis for this concept. The paper also substantiates the fact that presently one may observe a tendency towards a comprehensive understanding of the legal system, towards rejection of the formational approach in favour of the socio-cultural one, with regard for a number of other internal and external factors affecting the formation and functioning of the legal system. The novelty of the study was the conclusion that the concept of the legal system, as well as the categories derived from it, so far represent the basic theoretical function in formulating hypotheses, setting goals and objectives of comparative legal research. At the same time, the authors note that a unified approach to comprehending the essence, typology and classification of legal systems is objectively not possible in the conditions of multiple legal cultures and traditions of legal consciousness, which, ultimately, should be assessed as a positive stimulus for further research.
\end{abstract}

Keywords: comparative law, legal system, legal globalisation, legal glocalisation

\section{Introduction}

${ }^{1}$ Corresponding author: ur.vipe-35@mail.ru 
The relevance of the study is accounted for by the reorientation of comparative jurisprudence towards solving applied problems of legal interaction in the conditions of a search for a compromise between the processes of legal globalisation and glocalisation, and, as a consequence, by the need to revise the concept of the legal system as an object of comparative jurisprudence. Comparative jurisprudence, which was conceived as a response to the need to understand the integration processes, does not stay indifferent to solution of global problems, thus confirming R. David's conclusion that it is intended "for mutual understanding between peoples and creating the best possible regime of relations in the international life" [1]. It should be recognised that modern comparative legal research is increasingly focused on solving applied problems. The Internet accessibility of legal information, as well as globalisation processes, search for standard solutions of regional and international problems based on a compromise between the realities of time, economic and political situation, organisational and legal resources and national legal traditions determine the content and development of the legal science.

Standardisation of legal regulation as a means of forming stable legal spaces, preventing possible risks, violations or deviations from a certain norm, is becoming a popular means of legal interaction [2, pp. 105-106]. A due example is represented by interstate compliance programmes that establish quality standards for legal regulation [3, p. 13; 4, 5].

Along with globalisation, a number of other processes are evident: formation of trends, glocalisation, political and economic regional integration, preservation of cultural and national identity [6]. In fact, this is a defensive reaction of communities united by socio-cultural or statehood affinity against the cultural "erosion" [7, p. 245]. The consideration of processes of interstate legal interaction from the position of results of mutual influence of legal cultures, with regard for mutually complementing processes of globalisation and glocalisation, determines the vector of comparative legal research.

One should not ignore the strengthened role of the political factor in the processes of legal interstate interaction in the information-oriented society [8]. The international law, which has become a "factual tool of politics", is also one of the most significant means of legal acculturation $[9, \mathrm{p} .16]$.

The review of modern studies makes it possible to conclude that there is a forming tendency to change the focus of interest, from describing and comparing the external forms of existence of the legal reality to understanding the core of differing legal cultures, the peculiarities of legal consciousness and the influence of national legal traditions.

All of the above conditions engendered the need to review the concept of the main, purely theoretical, object of comparative jurisprudence - the legal system [10].

\section{$2 \quad$ Methods}

The methodological basis of the research is represented by such scientific methods as dialectical, logical, historical, predictive, systemic analysis and content analysis. This made it possible, in view of achievement of the said objective, to analyse the works of Russian and foreign comparativists, both the founders of modern comparative jurisprudence and novice researchers, as well as the materials of scientific conferences on the problem under study.

\section{Results and discussion}

Traditionally, scientific literature resorts to various approaches to formulating the concept of the legal system, towards understanding their structure, substance and classification. The 
complex integrative nature of the category "legal system", according to Matuzov, makes it possible to form a holistic picture of legal reality [11]. This position is shared by Chestnov who believes that legal reality can be theoretically constructed and reproduced within the framework of this category [12, p. 30]. A similar approach can be traced in the works by Alpatov and Grudtsyna [13, p. 129]. Consequently, most of the authors adhere to a broad understanding of the "legal system" as a set of regulatory, organisational, ideological and other structural elements $[14$, p. 22]. Along with the generalised concept, the clarified term "national legal system" is used, emphasising the affiliation of a legal system to a particular state [15, p. 61]. The said concepts are often used interchangeably, however with recognition of a possibility of exceptions from the general rule. An example is the presence of the juridical systems of England, Scotland and Northern Ireland in the national legal system of Great Britain.

The comprehension of a mixed legal system as uniting the elements of several legal traditions/families is also widely used by the researchers [16, p. 92]. Mixed systems represent a phenomenon stemming from the strengthening processes of legal and interstate integration, the presence of free information space, increased mobility of the population, etc. They may be temporary, as well as "migrating", for instance, connected with mass migration of the population (religious legal systems).

Saidov considers the possibility of typology of legal systems with regard for all those existing in the world (global typology), or with regard for the regional aspect (regional typology), and also points to the possibility of their hierarchy from "maternal", where "the original legal solutions were first generated", to "subsidiary", i.e. borrowed [17, pp. 157-162]. Chirkin singles out global legal systems that differ in their formational and principally civilisational qualities: Muslim system, liberal/semi-social capitalist system and the system of law of totalitarian socialism [14, p. 24].

In foreign comparative studies, the general criteria for classification of legal systems normally include the form of legal thought, ideology, structure and system of law and, additionally, legal tools [1], historical heritage and sources of law [18], as well as legal style and essential features of procedural law, organisation of judicial system [19, p. 127]. When identifying the general patterns of legal development of different states and the potential of legal unification and exchange of experience, the need for integrated classification of legal systems was engendered, which accounts for the use of the concepts "legal family", "legal circles", "legal civilisation" and others.

It should be noted that in Western comparative studies the issue of relationship between these concepts is not deemed relevant: most of the researchers consider them to be identical. An example is a classification proposed by "JuriGlobe" (a research group at the University of Ottawa) which supposes the use of the concept of "legal systems" in the plural, which means that the presence of common characteristics does not exclude tendencies to specification within each individual legal system, depending on the territory where the system is functioning [20].

David defined two criteria for the classification of legal families - ideological and technical/legal (trichotomy of legal families), distinguishing between the Romano-Germanic legal family, the common law family and the socialist law, while allowing for the existence of other families, for instance, the Islamic law [1, pp. 26-27]. The concept of Zweigert, Kötz, based on the idea of "legal style", does not lose its relevance as well: this includes in total the historical origin and development of a legal system, the dominant legal doctrine and ideology, specific legal institutions, sources and methods of their interpretation [18]. According to Hoecke, legal families should be classified on the basis of the structural approach since the differences between the legal systems in terms of 
content of particular rules are insignificant if these systems have common structural characteristics at the level of principles and concepts [21, p. 130].

In Russian comparative jurisprudence, of interest is the approach of Lafitsky who uses the principle of interaction between religion and law as a criterion for typology, highlighting the "Christian tradition of law" and the "Islamic tradition of law" [22, p. 98]. It can be stated that a fairly uniform approach to comprehension of the legal family has been developed in the Russian science - as "a set of national legal systems distinguished on the basis of commonality of sources, primarily mental, stylistic structures of the law and the historical specifics of its formation", which, however, does not preclude the discussion of different approaches to typology of modern legal families [11, p. 198].

Much attention is paid to unification of legal families; many scholars agree that two main antipode groups have developed in the context of legal globalisation: "Western law", which supposes "autonomy of the individual and non-interference on the part of the state, ideas of justice, freedom and equality (an example is the Anglo-Saxon and the Romano-Germanic systems), and "Eastern law" which is based on etatisation of the society, syncretism and sacral beliefs (religious and clan-specific traditional legal systems) [23, p. 31].

A.H. Saidov uses the concept of "legal civilisation", basing his arguments on the features of historical development, structure, characteristics of the main branches and sources of law; distinguishes between the Western and Eastern civilisation, analyses their essence, considering the historical development in a consistent way [17, pp. 156, 159-160].

The use of the legal civilisation concept is conditioned by the actualisation of the civilisational/cultural approach to comprehension of law in the context of differently-directional processes of globalisation and glocalisation. The authors believe that it is not principally correct to consider legal civilisations as an independent object of research, since the phenomena of legal reality are part of civilisation in its socio-cultural interpretation [24, p. 39].

It is interesting to follow some authorial approaches to comprehension and application of the concepts "legal system" and "legal family", using the example of structuring of training courses in "Comparative Law". Chirkin suggests studying the material in accordance with the theory of "global legal systems": Muslim legal system, totalitarian-socialist legal system (the author notes the peculiarity of law in North Korea, Vietnam, the presence of transitional families); liberal, partially-social capitalist legal system [25]. Saidov characterises the legal families on the whole (Romano-Germanic legal family), as well as some individual distinctive legal systems (Latin America, the system of socialist law, etc.), as well as Islamic law, conventional African law, etc. [17]. A number of foreign educational publications distinguish the general, African, Asian, Islamic, transnational and other systems of law as objects of study [26]. The analysis of educational publications confirms that the classification on the basis of integrative or sociocultural approaches is commonly used in the study of legal systems; increasingly more attention is paid to mixed legal systems as well as the issues of legal acculturation.

\section{Conclusion}

The notion of the legal system, as well as the categories derived from it, serve as a basic theoretical function in formulating hypotheses, setting goals and objectives of comparative legal research. The authors believe that the search of valid legal solutions to national, regional or general problems will be efficient only if the entire range of factors of external and internal impact on legal processes is taken into account: the state of legal system, the 
role of legal traditions, the peculiarities of legal culture, the influence of international law and politics, the mechanisms of interaction of various legal systems (families), the objective challenges of particular time periods.

With regard for the interdisciplinarity of comparative jurisprudence and the shift of the ongoing-research emphasis towards a practical footing, the authors can assert that the absence of a unified approach to comprehension of the essence as well as classification of legal systems is accounted for by the objective reasons, primarily the diversity of legal cultures and traditions of legal thought, which ultimately has a positive effect on the quality of research and encourages towards the search for "new knowledge".

\section{References}

1. R. David, K. Geoffrey-Spinozi, Basic legal systems of our time, trans. from French by V.A. Tumanov, 12, 26-27 (International Relations, Moscow, 2019)

2. V.F. Popondopulo, D.A. Petrov, Bulletin of St. Petersburg State University. Series 14. Law, 1, 102-112 (2020). https://doi.org/10.21638/spbu14.2020.107

3. Yu.A. Tikhomirov, Law. Journal of Higher School of Economics, 4, 4-17 (2017). Accessed on: February 26, 2021. [Online]. Available: https://cyberleninka.ru/article/n/pravovoe-prostranstvo-ravnovesie-i-otkloneniya

4. The International Compliance Association (ICA). Accessed on: February 26, 2021. [Online]. Available: https://www.int-comp.org/

5. National Association for promotion of the compliance system for establishing compliance of activities of organisations of any form of ownership with the norms of law, established regulatory rules and standards. Accessed on: February 26, 2021. [Online]. Available: https://www.compliance.su/

6. E. Örücü, D. Nelken, Comparative Law: A Handbook, 43 (Oxford and Portland, Oregon, 2007)

7. Li Tian-Qi, ANI: Economics and Management, 3(20), 244-246 (2017). Accessed on: February 27, 2021. [Online]. Available:

https://cyberleninka.ru/article/n/kontseptualnye-osnovy-razvitiya-glokalizatsii-kak-reak tsii-na-protsess-globalizatsii

8. R. Hirschl, Comparative Matters: The Renaissance of Comparative Constitutional Law, 9 (Oxford University Press, Oxford, 2014)

9. A.A. Malinovsky, E.N. Trikoz, International Processes, 18(2(61)), 6-30 (2020). https://doi.org/10.17994/IT.2020.18.2.61.2

10. M. Hoecke, Law as Communication, trans. from English by M.V. Antonov and A.V. Polyakov (Publishing House of Saint Petersburg State University, University Publishing Consortium, Saint Petersburg, 2012)

11. N.I. Matuzov, Theory of state and law: a course of lectures, in N.I. Matuzov, A.V. Malko (eds.) 181, 197 (Norma: INFRA-M, Moscow, 2020)

12. I.L. Chestnov, Russian Law Journal, 6(2), 28-34 (2019). https://doi.org/10.17816/RJLS18476

13. Yu.M. Alpatov, L.Yu. Grudtsyna, Bulletin of Moscow University of the Ministry of Internal Affairs of Russia, 1, 129-133 (2017). Accessed on: February 26, 2021. [Online]. Available: https://cyberleninka.ru/article/n/klassicheskie-i-sovremennye-kontseptsii-i-vzglyady-na -pravovye-sistemy-sovremennosti 
14. V.E. Chirkin, Law. Journal of Higher School of Economics, 4, 18-30 (2017). https://doi.org/10.17323/2072-8166.2017.4.18.30

15. S.V. Boshno, Law and Modern States, 2-3, 58-71. 2018https://doi.org/10.14420/ru.2018.2-3.5

16. E.N. Trikoz, Bulletin of Kutafin Moscow State Law University, 4(32), 91-97 (2017). https://doi.org/10.17803/2311-5998.2017.32.4.091-097

17. A.H. Saidov, Comparative Jurisprudence: An Academic Coursebook, 156-157, 159-162 (Norma: INFRA-M, Moscow, 2020)

18. K. Zweigert, H. Kötz, Introduction to Comparative Jurisprudence in Private Law: In 2 volumes. V.1. The Foundations, trans. from German, 108 (International Relations, Moscow, 1998)

19. C. Osakwe, Journal of Russian law, 5(173), 125-128 (2011)

20. Classification of legal systems and corresponding political entities. Accessed on: February 24, 2021. [Online]. Available: http://www.juriglobe.ca/eng/sys-juri/index-syst.php

21. M. Hoecke, News of Higher Educational Institutions. Jurisprudence, 3(308), 121-147 (2013)

22. V.I. Lafitsky (ed.), Comparative jurisprudence: national legal systems. V. 1. Legal systems of Eastern Europe, 98 (Contract: Institute of Legislation and Comparative Law under the Government of the Russian Federation, Moscow, 2012)

23. V.V. Denisenko, E.N. Trikoz, Legal science and practice: Bulletin of Nizhny Novgorod Academy of the Ministry of Internal Affairs of Russia, 2(42), 29-37 (2018). https://doi.org/10.24411/2078-5356-2018-10004

24. M.V. Nemytina, Bulletin of Kutafin Moscow State Law University, 4(32), 28-40 (2017). https://doi.org/10.17803/2311-5998.2017.32.4.028-040

25. V.E. Chirkin, Comparative Jurisprudence: A Coursebook for Graduate School Students (Norma: INFRA-M, Moscow, 2021). Accessed on: February 26, 2021. [Online]. Available: https://znanium.com/catalog/product/1176857

26. U. Kiscel, Comparative Law (Oxford University Press, Oxford, 2019) 